\section{Rust-spotted North American Ginseng Roots: Phenolic, Antioxidant, Ginsenoside, and Mineral Nutrient Content}

\author{
Cindy Campeau and John T.A. Proctor ${ }^{1}$ \\ Department of Plant Agriculture, Division of Horticultural Science, University \\ of Guelph, Guelph, Ontario N1G 2W1, Canada
}

Chung-Ja C. Jackson and H.P. Vasantha Rupasinghe

Guelph Center for Functional Foods, Laboratory Services, University of Guelph, Guelph, Ontario, N1H 8J7, Canada

Additional index words. Panax quinquefolius, periderm, rusty root, saponins

\begin{abstract}
Rusty root is a major problem in ginseng production worldwide as it reduces root quality. Full characterization of rusty root is unavailable, and necessary for development of effective control measures. A comparison of phenolics, antioxidants, ginsenosides, and mineral nutrient content of rusted and non-rusted tissue from disease-free roots is reported. Periderm and adjacent tissues of 4-year-old North American ginseng roots (Panax quinquefolius $\mathrm{L}$.) had a total phenolic content of $3.05 \mathrm{mg} \cdot \mathrm{g}^{-1}$ dry weight (as gallic acid equivalents), which was increased $53 \%$ by rust-spotting. Antioxidant activity increased with phenolic content and was $33 \%$ higher $\left(3.6 \mathrm{vs} .2 .7 \mathrm{mg} \cdot \mathrm{g}^{-1} \mathrm{dry}\right.$ weight as ascorbic acid equivalents) in rust-spotted tissue. Total ginsenoside content was higher (139.1 vs. 119.4 $\mathrm{mg}^{-\mathrm{g}^{-1}}$ ) in healthy than in rust-spotted tissue, the latter reflecting a significant decrease in four of the major ginsenosides $\left(R b_{2}, R c\right.$, $R d$, and $\left.R e\right)$. The $R g$ group was higher $\left(38.0\right.$ vs. $\left.29.9 \mathrm{mg}^{-1} \mathrm{~g}^{-1}\right)$ in healthy than in rust-spotted tissue. The mineral elements $\mathrm{N}, \mathrm{P}$, $\mathrm{Ca}, \mathrm{Mg}, \mathrm{Zn}, \mathrm{Mn}$, and $\mathrm{Fe}$ were higher, and $\mathrm{K}$ lower $(21 \%)$ in rust-spotted tissue than in healthy tissue.
\end{abstract}

Disease is a major constraint to ginseng production worldwide (Howard et al., 1994; Parke and Shotwell, 1989; Proctor, 1996; Punja, 1997; Yu and Ohh, 1995). Poor crop establishment is often due to seedling diseases caused by species of Fusarium, Rhizoctonia, and Pythium (Punja, 1997). Pathogens of mature roots include the seedling fungi, and Phytophthora and Cylindrocarpon species. Collectively, these pathogens can cause extensive foliar damage and drastically reduce root yield and quality.

The fungus Cylindrocarpon destructans (Zinssmeister) Scholtan is a soilborne pathogen causing disappearing root rot of ginseng (Brammall, 1994; Parke and Shotwell, 1989; Reeleder and Brammall, 1994; Ziezold et al., 1998). Plant pathologists often group disappearing root rot with rusty root. Although Parke and Shotwell (1989) found Cylindrocarpon and Fusarium in association with rusty root, they determined that these pathogens were not its cause. They suggested that rusty root is the result of a combination of biological

Received for publication 7 May 2002. Accepted for publication 18 Oct. 2002. This research was supported in part by J.C.K. Farms Ltd. and the Ontario Ministry of Agriculture, Food and Rural Affairs. We are indebted to Lindsay Park and Dean Louttit for technical assistance.

${ }^{1}$ To whom reprint requests should be addressed. E-mail: jtprocto@uoguelph.ca and nutritional factors, i.e., a physiological disorder. Rusty root symptoms in Cylindrocarpon-infected roots include raised, reddish-brown lesions (Brammall, 1994; Parke and Shotwell, 1989), whereas physiologically caused rust has orange-brown sunken lesions (Campeau, 2002). Further characterization of physiologically caused rusty root is warranted because of the above mentioned confusion. Also, the symptomology of rusty root of ginseng suggests involvement of phenolics, which have antioxidant activity in Asian ginseng (Panax ginseng C.A. Mayer) (Shin et al., 1990). Consumption of antioxidants has been associated with lower rates of mortality from coronary heart disease (Hertog et al., 1997), lung cancer (Knekt et al., 1997), and stroke (Keli et al., 1996).

The other chemical components of ginseng, and those with major biological activity, are ginsenosides (Proctor, 1996; Shibata et al., 1963) whose effects include cardio-protective, immunodulatory, anti-fatigue, and hepato-protective properties (But et al., 1995). The total and individual ginsenosides in leaf and root ginseng tissues are influenced by soil fertility (Konsler et al., 1990). Because of the interrelationship between the biological activity of ginseng constituents and mineral nutrition of the plant, this study was undertaken to investigate total phenolics, antioxidant activity, and elemental composition of rust-spotted ginseng tissue.
A. Total Phenolic Content and Antioxidant Activity Assays

Root sampling. Four-year-old ginseng roots were harvested in Oct. 2000 from a commercial farm in Ontario. At harvest roots were sorted into three categories: diseased (about $5 \%$ to $10 \%$ of the population), healthy, and those showing rust-spots (about $40 \%$ of the population). Rust-spots were orange-brown, sunken, round to irregular, and occurred randomly on the root. Diseased roots were discarded. Healthy and rust-spotted roots were stored at $3 \pm 0.2{ }^{\circ} \mathrm{C}$. Rust-spots were cut out along the outside margin of the spots using a two-sided razor blade and included the first 5-6 cell layers of the root tissue. Similar control samples were taken from healthy roots. Samples from rust-free areas on rust-spotted roots gave similar results to those from healthy roots confirming the localization of rust-spots (Campeau, 2002). The samples were dried for $48 \mathrm{~h}$ at $40{ }^{\circ} \mathrm{C}$ and then weighed, ground to a fine powder using a grinder (Black and Decker Coffee Bean), and stored at $-20^{\circ} \mathrm{C}$ until used for extraction.

Extraction procedure. The extraction procedure followed that of Lee et al. (2000), which had been used for Asian ginseng (Panax ginseng C.A. Meyer). Three samples, each of 0.5 $\mathrm{g}$ of dried tissue (composite samples from each of 25-40 roots) of rust-spots and three of the control were put into glass $125-\mathrm{mL}$ Erlenmeyer flasks. Twenty milliliters of $80 \%$ ethanol were added to each flask and placed in a $50{ }^{\circ} \mathrm{C}$ water bath for $2 \mathrm{~h}$. The extract was transferred into 50-mL plastic centrifuge tubes and centrifuged for 10 min at 3000 rpm using a Beckman model CS- 6 centrifuge. After centrifugation the clear supernatant was decanted from each tube and was either used immediately, or stored at -25 ${ }^{\circ} \mathrm{C}$, for the total phenolic content and antioxidant activity. All extractions were carried out in triplicate.

Spectrophotometric assays. Both total phenolic content and antioxidant activity in the ginseng root extracts were measured using spectrophotometric assays on a UV-visible spectrophotometer (Pharmacia LKB-Ultrospec Plus). The total phenolic content assay followed the Folin-Ciocalteu reaction (Singleton et al., 1999). Total antioxidant activity was determined using the ferric-reducing ability of plasma (FRAP) assay (Benzie and Strain, 1996).

\section{B. Ginsenoside Analysis}

Samples for ginsenoside analyses were obtained using the same sampling procedure described for the phenolic and antioxidant assays. Ginsenoside analysis was conducted following a modified and validated method based on Court et al. (1996a) and Li et al. (1996). Ginseng samples were dried at $40{ }^{\circ} \mathrm{C}$ for $48 \mathrm{~h}$, ground, and then passed through a 50 -mesh screen. One hundred milligrams of 
powder with $4 \mathrm{~mL}$ of $80 \%$ methanol and $20 \%$ $0.45 \mathrm{MKOH}(1: 1, \mathrm{v}: \mathrm{v})$ was sonicated at $50{ }^{\circ} \mathrm{C}$ for $1 \mathrm{~h}$. Samples were then neutralized using $350 \mu \mathrm{L}$ of $14 \% \mathrm{KH}_{2} \mathrm{PO}_{4}$, and the volume was made up to $10 \mathrm{~mL}$. Samples were centrifuged at $2000 \mathrm{rpm}$ for $10 \mathrm{~min}$ and an aliquot of supernatant was filtered through 0.22-micron nylon filters. The HPLC analysis was carried out using a Waters Symmetry $\mathrm{C}_{18}$ column. A gradient solvent system was used; solvent (A) acetonitrile and solvent (B) phosphate buffer (0.45 mm KH $\mathrm{PO}_{4}$, pH 5.8): $0-15 \mathrm{~min}, 20 \%$ to $20.9 \%$ (A); $15-15.5 \mathrm{~min}, 20.9 \%$ to $26 \%$ (A); 15.5-31.5 min, $26 \%$ to $27 \%(\mathrm{~A})$; $31.5-32 \mathrm{~min}$, $27 \%$ to $30 \%$ (A); $32-50 \mathrm{~min}, 30 \%$ to $33 \%$ (A); $50-60 \mathrm{~min}, 33 \%$ to $70 \%$ (A); 60-65 min, $70 \%$ to $75 \%$ (A); $65-65.5 \mathrm{~min}, 75 \%$ to $20 \%$ (A); 65.5-75 min, 20\% (A). The UV detection was monitored at an absorbance of $204 \mathrm{~nm}$. For the calculation of the recovery, a root sample was spiked with $\mathrm{Rg}_{1}$ and $\mathrm{Rb}_{2}$. The samples were quantified against external standards of each ginsenoside. Triplicate samples were analyzed from each of the healthy and the rust-spotted samples.

\section{Nutrient Analysis}

Powdered root samples were obtained using the same procedure described for the phenolic and the antioxidant assays. The mineral nutrient analysis of healthy and rust-spotted tissues was conducted by the Laboratory Services Division of the Univ. of Guelph following the methods set out in the Western States Laboratory Proficiency Testing Program Soil and Plant Analytical Methods (Gavlak et al., 1994).

\section{Statistical Analysis}

The comparison of healthy and rust-spotted tissues, in all three of the above experiments, was analyzed using the general linear model procedure of the Statistical Analysis System program package (SAS Institute Inc., Cary, N.C.). All data was normally distributed and tested using a probability of $P \leq 0.05$. Each experiment was carried out twice.

\section{Results and Discussion}

Total phenolics and antioxidant activity. Total phenolic concentration in healthy ginseng root was $3.05 \mathrm{mg} \cdot \mathrm{g}^{-1}$ dry weight (Table 1). This translates into $915 \mathrm{mg} \cdot 100 \mathrm{~g}^{-1}$ fresh weight, which is similar to that found in red grape, and higher than that found in many fruit crops (Kalt, 2001, Table 7.2). The total phenolic content of ginseng rust-spots was significantly higher $(53 \%)$ than that of healthy ginseng roots (Table 1 ). The increase of phenolic compounds is consistent with the assumption that phenolics are the cause of the browning called ginseng rust-spot (Campeau, 2002). Similar observations have been reported for russet spotting of lettuce (Hyodo et al., 1978). Lettuce exposed to ethylene had an increase in phenylalanine ammonia-lyase, an enzyme in the shikimic acid pathway, resulting in an increase in phenolic compounds and the development of brown spots (Hyodo et al.,
1978; Ke and Saltveit, 1988).

Nine phenolic compounds have been isolated from North American ginseng (Duke, 1992) and eight of them have antioxidant activity in ginseng or other plants (Han et al., 1985; Shahidi and Wanasundara, 1992; Shin et al., 1990). Therefore, the increase in the phenolic content of the rust-spotted tissue also resulting in a significant increase of $33 \%$ in antioxidant activity was expected and confirmed (Table 1). A linear relationship ( $r=$ 0.97 ) between total antioxidants and total phenolic content was found. Phenolic antioxidants play important roles as free radical terminators and, sometimes, as metal chelators (Shahidi and Wanasundara, 1992). Rapid donation of a hydrogen atom from phenolic antioxidants to lipid radicals results in the interference of lipid oxidation (Shahidi and Wanasundara, 1992). Maltol interferes with lipid peroxidation by forming a chelate specifically depriving the ferric ion (Han et al., 1985) and has antioxidant activity (Shin et al., 1990).

Ginsenosides. The total ginsenoside content was significantly higher for the healthy than for the rust-spotted samples with 139.1 and $119.4 \mathrm{mg} \cdot \mathrm{g}^{-1}$, respectively (Table 2 ). The total ginsenosides in our samples are higher than that reported by Court et al. (1996b) (139.1 vs. $75.9-78.3 \mathrm{mg} \cdot \mathrm{g}^{-1}$ ), reflecting the expected higher content in the periderm and adjacent tissues where ginsenosides are concentrated (Campeau, 2002; Kubo et al., 1980; Mei et al., 1990).

All six major ginsenosides previously reported in American ginseng (Shibata et al., 1963) were identified and four of them, $\mathrm{Rb}_{2}$, $\mathrm{Rc}, \mathrm{Rd}$, and Re, had significantly lower values in the rust-spotted than in the healthy tissues (Table 2). The most abundant ginsenosides were $\mathrm{Rb}_{1}$ and $\mathrm{Re}$, which accounted for $64.7 \%$ of the total in the healthy and $68.7 \%$ of the total in the rust-spotted tissue. These findings are similar to those of $\mathrm{Li}$ et al. (1996), where $\mathrm{Rb}_{1}$ and $\mathrm{Re}$ made up more than $75 \%$ of the total root ginsenoside content. In the healthy tissue the $\mathrm{Rb}$ group accounted for $71.4 \%$ of the total ginsenosides, while the Rg group accounted for $27.3 \%$ (Table 2). Wang et al. (1999) reported a similar relationship, significantly higher $\mathrm{Rb}$ group ginsenosides, in 2- and 3-year-old fieldgrown roots.

Overall, rust-spotting caused a significant decrease in four of the six major ginsenosides and in the total ginsenoside content of the root samples. Therefore, even though rust-spotting results in an increase in antioxidant activity, it had an adverse effect on root ginsenoside content. One explanation for this decrease may be due to the location of the ginsenosides primarily in the periderm and adjacent tissues of the root (Kubo et al., 1980; Tani et al., 1981). In this study the decrease of ginsenosides in the rust-spotted samples may be because ginseng rust-spot causes the destruction of the periderm, and in more severe cases the pericycle and secondary phloem, therefore resulting in the loss of secretory ducts. The destruction of this tissue may have an effect on the total ginsenoside content reported here because only the first 5-6 cell layers were sampled. In the healthy tissue the periderm and pericycle were sampled, but in rust-spots the periderm was mostly destroyed; therefore, samples were taken primarily from the pericycle and the secondary phloem where ginsenosides are less abundant.

Root elemental concentration. There was a significant increase of each element in the rust-spotted samples except for copper, boron, and potassium (Table 3). Copper and boron both tended to increase in rust samples. Potassium levels were significantly lower $(21 \%)$ in the rust-spotted samples. The amount of potassium in ginseng roots is positively correlated with the growth rate of ginseng roots (Konsler and Shelton, 1990); therefore, this decrease could reflect a corresponding decrease in overall root growth. An increase in manganese and zinc may also result in a decrease in root weight because there are negative correlations between root weight and manganese and root weight and zinc (Konsler and Shelton, 1990). At the present time the concern with ginseng rust-spot is the

Table 1. Total phenolic and antioxidant content of the first 5-6 cell layers of healthy and rust-spotted 4-year-old North American ginseng roots.

\begin{tabular}{lcc}
\hline Tissue & $\begin{array}{c}\text { Total phenolics } \\
\left(\mathrm{mg} \cdot \mathrm{g}^{-1} \text { dry wt as }\right. \\
\text { gallic acid equivalents })\end{array}$ & $\begin{array}{c}\text { Total antioxidants } \\
\left(\mathrm{mg} \cdot \mathrm{g}^{-1} \mathrm{dry} w \mathrm{ws}\right. \\
\text { ascorbic acid equivalents })\end{array}$ \\
\hline Healthy & $3.05^{z}$ & $2.7^{z}$ \\
Rust-spotted & 4.67 & 3.6 \\
\hline
\end{tabular}

${ }^{\mathrm{z}}$ Means within columns are significantly different at $P \leq 0.05, t$ test.

Table 2. Ginsenoside analysis of the first 5-6 cell layers of healthy and rust-spotted samples of 4-year-old North American ginseng roots.

\begin{tabular}{|c|c|c|c|c|c|c|c|c|c|c|}
\hline \multirow[b]{3}{*}{ Tissue } & \multicolumn{10}{|c|}{ Ginsenoside $\left(\mathrm{mg} \cdot \mathrm{g}^{-1}\right.$ dry weight $)$} \\
\hline & \multicolumn{5}{|c|}{ Rb group } & \multicolumn{3}{|c|}{ Rg group } & \multirow{2}{*}{$\frac{\text { Ro group }}{\text { Ro }}$} & \multirow{2}{*}{ Total } \\
\hline & $\mathrm{Rb}_{1}$ & $\mathrm{Rb}_{2}$ & $\mathrm{Rc}$ & $\mathrm{Rd}$ & Total & $\mathrm{Re}$ & $\mathrm{Rg}_{1}$ & Total & & \\
\hline Healthy & 57.3 & $3.4^{z}$ & $24.7^{z}$ & $14.0^{z}$ & $99.4^{2}$ & $32.7^{z}$ & 5.3 & $38.0^{z}$ & 1.7 & $139.1^{z}$ \\
\hline $\begin{array}{l}\text { Rust-spotted } \\
\text { Rust-spotted }\end{array}$ & 56.3 & 2.1 & 17.3 & 12.3 & 88.0 & 25.7 & 4.2 & 29.9 & 1.5 & 119.4 \\
\hline as $\%$ of healthy & 98.2 & 61.8 & 70.0 & 87.8 & 88.5 & 78.6 & 79.2 & 78.7 & 88.2 & 85.8 \\
\hline
\end{tabular}

${ }^{\mathrm{z}}$ Means within columns are significantly different at $P \leq 0.05, t$ test. 
Table 3. Elemental composition of the first 5-6 cell layers of healthy and rust-spotted samples of 4 year-old North American ginseng roots.

\begin{tabular}{|c|c|c|c|}
\hline Element & Healthy & Rust-spotted & $\begin{array}{c}\text { Rust-spotted as } \\
\% \text { of healthy }\end{array}$ \\
\hline & \multicolumn{2}{|c|}{ Dry weight (\%) } & \\
\hline N & 1.12 & $1.30^{\mathrm{z}}$ & 116 \\
\hline $\mathrm{P}$ & 0.19 & $0.24^{\mathrm{z}}$ & 123 \\
\hline K & 2.91 & $2.30^{\mathrm{z}}$ & 79 \\
\hline $\mathrm{Ca}$ & 0.50 & $0.70^{\mathrm{z}}$ & 140 \\
\hline \multirow[t]{2}{*}{$\mathrm{Mg}$} & 0.26 & $0.30^{\mathrm{z}}$ & 115 \\
\hline & \multicolumn{2}{|c|}{ Dry weight $\left(\mathrm{mg} \cdot \mathrm{g}^{-1}\right)$} & \\
\hline $\mathrm{Cu}$ & 12.0 & 12.7 & 106 \\
\hline $\mathrm{Zn}$ & 27.0 & $33.0^{z}$ & 122 \\
\hline $\mathrm{Mn}$ & 43.0 & $66.3^{z}$ & 154 \\
\hline B & 28.3 & 29.3 & 104 \\
\hline $\mathrm{Fe}$ & 296.0 & $490.3^{z}$ & 166 \\
\hline
\end{tabular}

${ }^{z}$ Means across columns are significantly different at $P \leq 0.05, t$ test.

reduction of the quality of the roots rather than root weight, which is the economic yield (Yingping et al., 1997). However, in severe cases where entire fields are affected, the decrease in potassium and increase in manganese and zinc, may result in a decrease in the average weight of the roots produced.

Iron in the periderm of Oriental ginseng is positively correlated with the occurrence of ginseng rust-spot (Yingping et al., 1997). In this study iron increased by $66 \%$ in the rust areas, which was the highest increase of all the elements (Table 3). Elemental composition of healthy 4-year-old North American ginseng whole roots was investigated by Khwaja et al. (1984) and compared to the elemental compostion of the first 5-6 cell layers of the healthy roots analyzed here. The macronutrients were similar between the two analyses. Potassium and manganese were slightly lower in the whole roots. All the micronutrients, except iron, were higher in the sample of just the 5-6 layers. The iron was almost 2.5 times higher in the whole roots.

In conclusion, the increase in phenolics in rust-spots confirms that the oxidation of phenolics is responsible for the orange-brown symptoms observed in ginseng rust-spot. The increase in the antioxidant activity of rust-spotted samples could be advantageous to the ginseng market if only the periderm was used in processing, which is not the case. Since rust-spots usually cover only a small portion of the surface of roots, the higher antioxidant levels may not be considerable when whole roots are processed. The same may occur in the ginsenoside analysis. The decrease in total ginsenoside content of rust-spotted samples should be investigated on a whole-root basis because the decrease may not be significant when entire roots are processed. Any studies to investigate ways to increase total antioxidant activity and ginsenoside content of whole roots would be beneficial and may change the view of the ginseng market where, for the most part, the size and appearance of the roots are used to establish quality.

The work on mineral nutrient concentration in roots showed differences in control and rust-spotted tissues. This finding suggests that field, and probably complementary greenhouse and laboratory studies, are needed to establish the soil and plant characteristics where rust-spotted roots are found. Field locations where rust-spotted roots are found are often poorly drained, and may have high levels of undecomposed manure, which may be high in ammonia and reducing substances. Yingping et al. (1997), working in China with Panax ginseng, have implicated iron, manganese, and boron, and high water-holding capacity of the soil in rust-spot induction in ginseng.

The symptoms and causes of rust-spot of ginseng are similar to cavity spot of carrots (Guba et al., 1961; Perry and Harrison, 1979a, 1979b; Scaife et al., 1980). Of particular relevance to ginseng were the findings that cavity spot was correlated with soil ammonium and pH (Scaife et al., 1980). Also, soil nitrate and ammonium were associated with each other, and their ratio was correlated with exchangeable manganese. Waterlogging and compaction bring about reducing conditions that lead to high available manganese.

\section{Literature Cited}

Benzie, I.F.F. and J.J. Strain. 1996. The ferric reducing ability of plasma (FRAP) as a measure of "antioxidant power": The FRAP assay. Anal. Biochem. 239:70-76.

Brammall, R.A. 1994. Disappearing root rot, p. 296-297. In: R.J. Howard, J.A. Garland, and W.L. Seaman (eds.). Diseases and pests of vegetable crops in Canada. Can. Phytopathol. Soc. Entomol. Soc. Can., Ottawa.

But, P.P.H., S.Y. Hu, and H. Cao. 1995. The ginseng plant; products and quality, p. 24-34. In: W.G. Bailey, C. Whitehead, J.T.A. Proctor, and J.T. Kyle (eds.). Proc. Intl. Ginseng Conf. Vancouver 1994, Canada.

Campeau, C.A. 2002. Effects of ethephon on floral abscission and root quality of North American ginseng (Panax quinquefolius L.). Univ., of Guelph, Ontario, Canada, MSc. Diss.

Court, W.A., J.G. Hendel, and J. Elmi. 1996a. High performance reversed phase liquid chromatographic determination of ginsenosides of Panax quinquefolius. J. Chromatogr. 755:11-17.

Court, W.A., L.B. Reynolds, and J.G. Hendel. 1996b. Influence of root age on the concentration of ginsenosides of American ginseng (Panax quinquefolius). Can. J. Plant Sci. 76:853-855.

Duke, J.A. 1989. Ginseng: A concise handbook. Reference Publ., Algonac, Mich.

Gavlak, R.G., D.A. Horneck, and R.O. Miller. 1994. Plant, soil, and water reference methods for the western region. Western Reg. Ext. Publ. 125.

Guba, E.E., R.E. Young, and T. Ui. 1961. Cavity spot disease of carrots and parsnip roots. Plant Dis. Rptr. 45:102-105.

Han, B.H., M.H. Park, and Y.N. Han. 1985. Studies on the antioxidant components of Korean ginseng: V. The mechanism of antioxidant activity of maltol and phenolic acid. Korean Biochem. J. 18:337-340.

Hertog, M.G.L., E.J.M. Feskens, and D. Kromhout. 1997. Antioxidant flavonols and coronary heart disease risk. Lancet 349:699.

Howard, R.J., J.A. Garland, and W.L. Seaman. 1994. Diseases and pests of vegetable crops in Canada. Can. Phytopathol. Soc. Entomol. Soc. Can., Ottawa.

Hyodo, H., H. Kuroda, and S.F. Yang. 1978. Induction of phenylalanine ammonia-lyase and increase in phenolics in lettuce leaves in relation to the development of russet spotting caused by eth- ylene. Plant Physiol. 62:31-35.

Kalt, W. 2001. Health functional phytochemicals of fruit. Hort. Rev. 27:269-315.

Ke, D. and M.E. Saltveit. 1988. Plant hormone interaction and phenolic metabolism in the regulation of russet spotting in iceberg lettuce. Plant Physiol. 88:1136-1140.

Keli, S.O., M.G.L. Hertog, E.J.M. Heskens, and D. Kromhout. 1996. Dietary flavonoids, antioxidant vitamins and incidence of stroke. Arch. Intern. Med. 156:637-642.

Khwaja, A., R. Roy, and M.A. Rouf. 1984. Ginseng (Panax quinquefolium L.) plant tissue, roots and soil testing for fertilizer recommendations, $\mathrm{p}$. 116-138. In: J.T.A. Proctor (ed.). Proc. $6^{\text {th }}$ North Amer. Ginseng Conf., Univ. of Guelph, Ontario, Canada.

Knekt, P., R. Järvinen, R. Seppänen, M. Heliövaara, L. Teppo, E. Pukkala, and A. Aromaa. 1997. Dietary flavonoids and the risk of lung cancer and other malignant neoplasms. Amer. J. Epidemiol. 146:223-230

Konsler, T.R. and J.E. Shelton. 1990. Lime and phosphorus effects on American ginseng: I. Growth, soil fertility, and root tissue nutrient status response. J. Amer. Soc. Hort. Sci. 115: 570-574.

Konsler, T.R., S.W.Zito, J.E. Shelton, and E.J. Staba. 1990. Lime and phosphorus effects on American ginseng: II. Root and leaf ginsenoside content and their relationship. J. Amer. Soc. Hort. Sci. 115:575-580.

Kubo, M., T. Tani, T. Katsuki, K. Ishizaki, and S. Arichi. 1980. Histochemistry. I. Ginsenosides in ginseng (Panax ginseng C.A. Meyer) root. J. Nat. Prod. 43:278-284.

Lee, J.W., J.H. Do, S.K. Lee, and J.W. Yang. 2000. Determination of total phenolic compounds from Korean red ginseng, and their extraction conditions. J. Ginseng Res. 24:64-67.

Li,T.S.C., G. Mazza,A.C. Cottrell, and L. Gao. 1996. Ginsenosides in roots and leaves of American ginseng. J. Agr. Food Chem. 44:717-720.

Mei, L., L. Rui-Jun, and L. Ming-Yuan. 1990. The initiation and pattern of growth of resin ducts in the main roots of ginseng (Panax ginseng). Phytomorphology 40:17-20.

Parke, J.L. and K.M. Shotwell. 1989. Diseases of cultivated ginseng. Univ. of Wisconsin Ext. Res. Bul. 3465.

Perry, D.A. and J.G. Harrison. 1979a. Cavity spot of carrots I. Symtomatology and calcium involvement. Ann. Appl. Biol. 93:101-108.

Perry, D.A., and J.G. Harrison. 1979b. Cavity spot of carrots II. The effect of soil conditions and the role of pectolytic anaerobic bacteria. Ann. Appl. Biol. 93:109-115.

Proctor, J.T.A. 1996. Ginseng: Old crop, new directions, p. 565-577. In: J. Janick (ed.). Progress in new crops, Proc. $3^{\text {rd }}$ Natl. Symp., New Crops: New opportunities, new technologies. ASHS Press, Alexandria, Va.

Punja, Z.K. 1997. Fungal pathogens of American ginseng (Panax quinquefolium) in British Columbia. Can. J. Plant Pathol. 19:301-306.

Reeleder, R.D. and R.A. Brammall. 1994. Pathogenicity of Cylindrocarpon destructans, and Rhizoctonia solani to ginseng seedlings in Ontario. Can. J. Plant Pathol. 16:311-316.

Scaife, M.A., A.K. Burton, and M.K. Turner. 1980 Cavity spot of carrots - An association with soil ammonium. Commun. Soil Sci. Plant Anal. 11: 621-628.

Shahidi, F. and P.K.J.P.D. Wanasundara. 1992. Phenolic antioxidants. Crit. Rev. Food Sci. Nutr. 32:67-103.

Shibata, S., O. Tanaka, M. Sado, and S. Tsuchima. 1963. The genuine saponin of ginseng. Tetrahedron Lett. 12:795-800. 
Shin, J.G., J.W. Park, J.K. Pyo, M.S. Kim, and M.H. Chung. 1990. Protective effects of a ginseng component, maltol (2-methyl-3-hydroxy-4-pyrone) against tissue damages induced by oxygen radicals. Korean J. Ginseng Sci. 14:187-190.

Singleton, V.L., R. Orthofer, and R.M. LamuelaRaventos. 1999. Analysis of total phenols and other oxidation substrates and antioxidants by means of Folin-Ciocalteu reagent. Methods in Enzymol. 299:152-178.

Tani, T., M. Kubo, T. Katsuki, M. Higashino, T.
Hayashi, and S. Arichi. 1981. Histochemistry. II. Ginsenosides in ginseng (Panax ginseng) root. J. Nat. Prod. 44:401-407.

Wang, X., J.T.A. Proctor, Y. Kakuda, S. KrishnaRaj, and P.K. Saxena. 1999. Ginsenosides in American ginseng: Comparison of in vitro derived and field-grown plant tissues. J. Herbs Spices and Medicinal Plants 6:1-10.

Yingping, W., L. Zhihong, S. Yanjun, G. Shiwei, T. Shuzhen, and L. Zhaorong. 1997. Studies in genesis of ginseng rust-spots. Korean J. Ginseng
Sci. 21:69-77.

Yu, Y.H. and S.H. Ohh. 1995. Problems and present status of research on ginseng diseases in Korea, $\mathrm{p}$. 120-130. In: W.G. Bailey, C. Whitehead, J.T.A. Proctor, and J.T. Kyle (eds.). Proc. Intl. Ginseng Conf. Vancouver 1994, Canada.

Ziezold, A.M., R. Hall, R.D. Reeleder, and J.T.A. Proctor. 1998. Effect of drenching soil with benomyl, propiconazole, and fluazinam on incidence of disappearing root rot of ginseng. J. Ginseng Res. 22:237-243. 